P. JESU PUDUMAI DOSS SDB

Facoltà di Diritto Canonico

dell'Università Pontificia Salesiana, Italia

ORCID: 0000-0001-9755-6221

\title{
INCONTRO TRA DIRITTO ECCLESIALE E CULTURA INDIANA: CENNI STORICI E SFIDE ATTUALI
}

Contenuto: -1 . Una breve lettura storica delle realtà culturali indiane. 1.1. Cultura giuridica indiana. - 1.1.1. L'Induismo antico. - 1.1.2. L'influsso mussulmano. - 1.1.3. L'introduzione del sistema inglese. - 1.1.4. Il moderno complesso sistema legislativo indiano: Sistema misto. - 1.2. Cultura ecclesiale indiana. - 1.2.1. Origini apostoliche. - 1.2.2. Connessione siriaca e caldea. - 1.2.3. Inizio del Padroado portoghese. - 1.2.4. Interventi della Congregazione de Propaganda Fide. - 1.2.5. Realtà attuale della Chiesa cattolica. - 2. Alcune sfide attuali. - 2.1. Nella società civile. - 2.1.1. Riconoscimento legale della Chiesa. - 2.1.2. Alcune implicazioni legislative. - 2.2. Nella Chiesa. - 2.2.1. Adattamento del diritto canonico. - 2.2.2. Rapporto tra le Chiese sui iuris. - 2.2.3. Uguaglianza nella Chiesa. - 2.2.4. Inculturazione e dialogo. - Conclusione.

«Una cultura colma di saggezza, ricca di umana esperienza e di valori spirituali che valorizzano Dio e la sua provvidenza nella storia dell'uomo», ${ }^{1}$ con queste espressioni San Giovanni Paolo II rendeva «un rispettoso omaggio all'antica cultura» dell'India. Parlare, quindi, dell'incontro tra il diritto ecclesiale e la cultura giuridica indiana,

\footnotetext{
${ }^{1}$ Giovanni Paolo II, Discorso È difficile ai vescovi dell'India in visita ad limina apostolorum, 23 giugno 1979, in https://w2.vatican.va/content/john-paul-ii/ it/speeches/1979/june/documents/hf_jp-ii_spe_19790623_ad-limina-india.html (consultato il 12 ottobre 2018).
} 
richiede di compiere prima una breve lettura storica delle realtà culturali indiane, per poi cogliere le sfide attuali, che tale incontro ha provocato, nella società civile e nella Chiesa.

\section{Una breve lettura storica delle realtà culturali indiane}

L'India è davvero una «terra di molte religioni e di un ricco patrimonio culturale». Si richiamano qui alcuni aspetti essenziali della cultura giuridica indiana e del suo sviluppo storico, assieme alla storia delle Chiese in India.

\subsection{Cultura giuridica indiana}

La cultura giuridica indiana contemporanea è solo il punto di arrivo di una grande ricchezza di fonti giuridiche religiose, ${ }^{2}$ la cui storia può essere suddivisa essenzialmente in quattro tappe: l'Induismo antico, l'influsso mussulmano, l'introduzione del sistema inglese, e il moderno complesso sistema legislativo.

\subsubsection{L'Induismo antico}

L'induismo antico, chiamato anche Sanätanadharma che significa «legge/religione eterna», è un insieme di correnti religiose basate su antichi testi sacri induisti che fanno riferimento alle credenze religiose prima delle popolazioni della Valle dell'Indo e poi dell'intero popolo dell'India ${ }^{3}$. Gli antichi testi sacri sono raggruppati come $\hat{S}_{r u t i}{ }^{4}$

2 «In una ipotetica genealogia del diritto indiano, che parta dal diritto vedico e dravidico e arrivi a genitori che potrebbero essere individuati in common law inglese, diritto hindu e diritto musulmano, non vi è spazio per genitori di civil law...». Domenico Francavilla, Il modello giuridico italiano in India, in: Sabrina Lanni - Pietro Sirena (Eds.), Il modello giuridico - scientifico e legislativo - italiano fuori dell'Europa, Edizioni Scientifiche Italiane, Napoli 2013, p. 429.

${ }^{3}$ Cf. Sumeet Malik (Ed.), V.D. Kulshreshta's Landmarks in Indian Legal and Constitutional History, Eastern Book Company, Lucknow ${ }^{11} 2016$, pp. 4-17; SHIVA G. BAJPAI, The History of Hindu India. From Ancient to Modern Times, Himalayan Academy Publications, Hawaii 2011, pp. 1-8; Central BoArd of Secondary EduCATion, Legal Studies. Class XI, Unit III. Historical Evolution of the Indian Legal System, pp. 132-134.

${ }^{4}$ Sruti comprende quattro Saṃhitā, composte tra il 2000 a.C. e il 1100 a.C., intitolate Rgveda, Sāmaveda, Yajurveda e Atharvaveda, inoltre 11 Brāhmaṇa, commentari 
termine che indica la conoscenza "udita" dal principio dei tempi e trasmessa oralmente dalla casta sacerdotale dei brahmani, e come Smrti, ${ }^{5}$ vocabolo che indica una conoscenza sacra "ricordata" di generazione in generazione e raccolta da alcuni esperti. La Costituzione Indiana, nell'art. 25, Explanation $I I,{ }^{6}$ include tra gli indù anche gli appartenenti al buddismo, ${ }^{7}$ al jainismo ${ }^{8}$ e al sikhismo ${ }^{9}$.

alle quattro samithā composti tra il 1100 a.C. e l'800 a.C., e poi $4 \bar{A}$ ranyaka, testi esoterici riservati agli eremiti delle foreste o recitati al di fuori dei villaggi, composte tra il 1100 e l'800 a.C., e infine 14 principali Upanișad vediche, opere di ulteriore approfondimento filosofico-religioso, composte tra l'800 e il 500 a.C. Cf. MALIK (Ed.), V.D. Kulshreshta's Landmarks in Indian Legal and Constitutional History, pp. 4-5.

${ }^{5}$ Smrti comprende 6 Vedānga, che sono manuali di riti per il culto e insieme testi di grammatica, astrologia e astronomia, composti intorno al V-IV secolo a.C., intitolati Kalpa, Śikṣā, Nirukta, Chandas, Jyotișa e Vyakāraṇa, inoltre 4 upānga di 18 Purāṇa, 4 Dharmaśāstra, Nyāya e Mìmāmnsā, e infine 2 poemi epici di Mahābhārata (che ha al suo interno il Bhagavadgītā) e Rāmāyaṇa. Cf. MALıK (Ed.), V.D. Kulshreshta's Landmarks in Indian Legal and Constitutional History, p. 5.

${ }^{6}$ Art. 25, «Explanation II. In sub-clause (b) of clause (2), the reference to Hindus shall be construed as including a reference to persons professing the Sikh, Jaina or Buddhist religion, and the reference to Hindu religious institutions shall be construed accordingly». The Constitution of India (as on $9^{\text {th }}$ November 2015), Published by Government of India - Ministry of Law and Justice (Legislative Department), p. 13, in http://lawmin.nic.in/olwing/coi/coi-english/coi-4March2016.pdf (consultato il 02 ottobre 2018).

${ }^{7}$ Il buddhismo (o buddha-śāsana) è la religione fondata da Siddhārtha Gautama (sec. VI-V a.C.) e basata sui Quattro nobili verità (esistenza, causa e estinzione della sofferenza e il sentiero che conduce all'estinzione) e propone gli Otto nobili sentieri (Retta Comprensione, Retto Pensiero, Retta Parola, Retta Azione, Retti Mezzi di Sussistenza, Retto Sforzo, Retta Presenza Mentale, Retta Concentrazione). Si notano le sue varie scuole di pensiero e vissuto (Theravāda, Mahāyāna e Vajrayāna) e le sue antiche università antiche: Taxila o Takshashila (VI-V sec a.C.), Pushpagiri (III sec d.C.), Nalanda (V sec d.C.).

${ }^{8}$ Il jainismo, fondata da Vardhamāna o Jina il Vittorioso (sec.VI a.C.), segue i 5 "grandi voti" (mahāvrata): ahimssā (non violenza), asatyatyāga (rinuncia alla menzogna), asteya (non rubare), brahmacarya (castità assoluta), aparigraha (privazione o non attaccamento).

${ }^{9}$ Il sikhismo (sec.XV-XVII), fondato dai suoi dieci guru, iniziando dal primo Guru Nanak Dev (1469-1539 d.C.), è una religione monoteista che chiede di evitare 
Il Dharmaśástra ${ }^{10}$ degli indù contiene i codici di diritto scritti in sanscrito: i Dharma-sutras sono "i fili o le stringhe di giustizia"; gli Smritis sono i trattati legali brevi; i Nibandhas sono i digesti delle leggi; e i Vrittis sono i commentari degli smritis. Essi espongono primariamente l'organizzazione societaria antica basata sui quattro Varnas (sistema indù di caste): ${ }^{11}$ il brähmaṇa con le funzioni sacerdotali o religiose; il kșatriya con le funzioni guerriere o politico-amministrative; il vaiśya con le attività lavorative o commercio; e il śúdra con i lavori servili. Presentano anche l'organizzazione familiare, basata sul sistema di famiglia allargata (joint family system) con i 4 Aśramas che sono gli stadi della vita di un indù ${ }^{12}$. Ogni indù è chiamato inoltre a vivere i 4 Puruṣārtas che sono i quattro scopi legittimi della vita. ${ }^{13}$ Oltre a tale strutturazione di vita individuale e sociale dell'antica

i "Cinque ladri" di lussuria, rabbia, avidità, attaccamento e inganno, oltre ad eliminare ogni differenza tra le persone, sulla base di casta, di ricchezza, ecc.

${ }^{10}$ Il Dharmaśāstra comprende i seguenti "codici" giuridci: i Dharma-sutras (600100 a.C) di Gautama, Baudhayana, Vaisistha e Apastamba; gli Smritis in particolare di Manusmriti (200 a.C -200 d.C), Yajnavalkya Smriti (200-500 d.C), Naradasmriti (100 a.C- 400 d.C), Visnusmriti (700-1000 d.C), Brhaspatismriti (200-400 d.C), e Katyayanasmriti (300-600 d.C); i Nibandhas; e i Vrittis. Va notata l'importanza del Manusmriti diviso in 2694 versetti e 12 capitoli: Creazione; Educazione; Matrimonio; Economia; Dieta, purificazione e donne; Devozione; Governo; Legge; Classi commerciali e servili; Classi miste; Pena e espiazione; Trasmigrazione e beatitudine finale. Cf. MALIK (Ed.), V.D. Kulshreshta's Landmarks in Indian Legal and Constitutional History, pp. 5-6.

${ }^{11}$ Cf. MaLiK (Ed.), V.D. Kulshreshta's Landmarks in Indian Legal and Constitutional History, pp. 6-9.

${ }^{12}$ Gli stadi della vita di un indù sono: Brahmācarya che s'inizia con il rito dello upanayana diventando così un giovane studente religioso; Gärhasthya che indica lo stato di matrimonio e capofamiglia, che s'incomincia con le abluzioni snāna; Vānaprastha che indica colui che dimora nella foresta, meditando sul Veda e praticando lo yoga e l'ascesi e che s'inizia solo quando avrà visto i figli dei figli; e Samnyāsa che è l'ultimo stadio di vita diventando un asceta errante e rinunciando totalmente il mondo.

${ }^{13}$ I quattro scopi legittimi della vita di un indù sono: Artha (ricchezza materiale); Kāma (piaceri e desideri anche sessuali); Dharma (giustizia); e Mokșa o mukti (liberazione assoluta e ultima). 
India, è rilevabile anche una certa organizzazione sia amministrativa sia giudiziaria. ${ }^{14}$

\subsubsection{L'influsso mussulmano}

La presenza mussulmana in India ${ }^{15}$ ha inizio con il commercio degli arabi soprattutto gli mussulmani arabi nel sud dell'India (sec. VII). Seguono poi le varie conquiste da parte dei mussulmani (VIII-XII sec), iniziando da Muhamed Ibin Quasim (712 d.C.) fino a Muhammed Ghori (1206 d.C.). Compaiono quindi i sultanati islamici, dove i Sultani si consideravano rappresentanti dei Califf, sotto varie dinastie: Mamelucchi (1206-1290 d.C.), Khalji (1290-1320 d.C.), Tughlak (1320-1413 d.C.), Sayyid (1414-1451 d.C.), Lodi (1451-1526 d.C.) e Moghul (1526-1707 d.C.). La dominazione islamica raggiunge il culmine con l'impero Moghul, soprattutto con l'imperatore Akbar il Grande (1542-1605 d.C.).

Gli imperatori mussulmani seguivano il corano e la sharia, soprattutto nei riguardi dei mussulmani. ${ }^{16} \mathrm{E}$ ben nota la collezione Fatawa-e-Alamgiri (o Fatawa-i-Hindiya), ${ }^{17}$ il codice in 33 volumi con tutti i principi essenziali del sistema hanafi della legge musulmana, compilato con l'aiuto di 500 esperti dall'imperatore moghul Aurangazeb (1665 d.C.). Anche in questo caso dell'applicazione delle leggi islamiche e/o secolari sotto vari imperatori, ${ }^{18}$ si possono cogliere vari

\footnotetext{
${ }^{14}$ Cf. Malik (Ed.), V.D. Kulshreshta's Landmarks in Indian Legal and Constitutional History, pp. 9-18.

${ }^{15}$ Cf. Humayun Kabir, Islam in India, in: Haridas Bhattacharyya (Ed.), The Cultural Heritage of India, Volume IV. The Religion, The Ramakrishna Mission Institute of Culture, Calcutta, 1956, pp. 579-592; K.K. Abdul Rahiman, History of the Evolution of Muslim Personal Law in India, in Journal of Dharma 11 (1986) pp. 250-251.

${ }^{16}$ Cf. Malik (Ed.), V.D. Kulshreshta's Landmarks in Indian Legal and Constitutional History, pp. 18-23.

${ }^{17}$ Cf. Rahiman, History of the Evolution of Muslim Personal Law in India, pp. 251-252.

${ }^{18}$ Si può individuare l'estensione dell'applicazione delle leggi islamiche e secolari nei seguenti ambiti: i) Diritto civile: la legge puramente personale dell'Islam su eredità, successione, diritto di famiglia, tutela, ecc., applicata solo ai musulmani, e
} 
elementi giuridici circa l'organizzazione societaria, come la cittadinanza e le tasse dei non cittadini, circa l'organizzazione amministrativa, come sultanato, province, distretti, pargana (gruppo dei villaggi), villaggi, e circa l'organizzazione giudiziaria con i vari tipi e livelli di tribunali (civili e criminali), le procedure giudiziarie, l'organizzazione dei giudici e avvocati, ecc. ${ }^{19}$

\subsubsection{L'introduzione del sistema inglese}

Prima con il commercio e poi la conquista da parte dell'Inghilterra, in India viene introdotto il sistema legale inglese che ha visto due fasi. ${ }^{20}$

Nella prima fase (1772-1833), avviene la compilazione e la traduzione in inglese dei testi antichi di diritto indù e mussulmano. Per l'applicazione di tale diritto, i giudici inglesi usufruivano dell'ausilio di esperti del diritto indù e mussulmano (Qadis o Maulavis). ${ }^{21}$ Per i mussulmani, si trattava di tradurre il Fatawa-e-Alamgiri (o Fatawa-i-Hindiya) dell'imperatore moghul Aurangazeb. In questa collezione, compaiono le leggi sui seguenti ambiti: personale, familiare, proprietà, relazioni interreligiose, transazioni e commercio, tassazione, ecc. ${ }^{22}$ Per quanto riguarda gli indù, il Vivadarnava Setu,

la parte secolare del diritto civile su commercio, contratto, ecc., applicata ai musulmani e ai non musulmani; ii) Leggi consuetudinarie su diritto tributario, applicato a tutti anche ai musulmani; iii) Leggi religiose e personali dei non-musulmani: come il diritto antico indù applicato con l'aiuto degli esperti indù; iv) Diritto Penale, applicando la sharia solo ai musulmani; v) Editi e Ordinanze con la legge comune per tutto il popolo. Cf. Rahiman, History of the Evolution of Muslim Personal Law in India, pp. 252-253.

${ }^{19}$ Cf. MALiк (Ed.), V.D. Kulshreshta's Landmarks in Indian Legal and Constitutional History, pp. 23-34.

${ }^{20}$ Cf. Central Board of Secondary Education, Legal Studies. Class XI, Unit III. Historical Evolution of the Indian Legal System, p. 135.

${ }^{21}$ La prassi dell'amministrazione della giustizia secondo il diritto indù o mussulmano da parte dei giudici inglesi con l'ausilio di vari "esperti" viene sancita con The Regulating Act del 1772 e del 1780. Cf. Rahiman, History of the Evolution of Muslim Personal Law in India, pp. 253-255.

${ }^{22}$ Cf. Rahiman, History of the Evolution of Muslim Personal Law in India, pp. 251-252. 
chiamato anche il "Codice Gentoo" o il "Codice delle leggi di Gentoo" viene compilato e tradotto nel 1776 da N.B. Halhed, su richiesta del Governatore Warren Hastings. Anche il Vivada Bhangarnava, chiamato anche il "Digesto di Jagannatha o di Colebrooke" su contratti e successioni, viene compilato da Jagannatha Turkapunchanana e tradotto nel 1797 da Colebrooke, su richiesta di Sir William Jones.

La seconda fase (1833-1947) consiste nell'elaborazione dei processi legislativi e di un sistema giuridico codificato: il The India Charter Act 1833 costituisce l'Indian Law Commission formata da esperti di diritto indù incaricata di aggiornare o emendare le leggi; e promulgare le seguenti leggi: The Code of Civil Procedure 1859, The Penal Code 1860, The Code of Criminal Procedure 1861, The Indian High Court's Act 1861 che ristruttura tutti i livelli di tribunali attribuendo l'ultimo appello al Comitato giudiziale di Privy Council a Londra e introducendo in questo modo alcuni concetti e principi inglesi nel sistema legale e giudiziario dell'India, e The Government of India Act 1935 che crea la Corte federale la quale poi diventerà la Corte Suprema dell'India nel 1950. Inoltre, vengono create alcune leggi per cambiare talune "tradizioni" non compatibili con la dignità umana: The Hindu Widow's Remarriage Act 1856; The Native Convert's Marriage Dissolution Act 1866; The Child Marriage Restraint Act 1929; e The Hindu Married Women's Right to Separate Residence and Maintenance Act 1944.

\subsubsection{Il moderno complesso sistema legislativo indiano: Sistema misto}

Il moderno complesso sistema legislativo dell'India può considerarsi come un "Sistema misto". ${ }^{23}$ L'India ha come legge fondamentale dello Stato e vertice nella gerarchia delle fonti giuridiche la

\footnotetext{
${ }^{23}$ «L'emancipazione del diritto indiano dal diritto inglese e l'elaborazione di una jurisprudence propriamente indiana è passata attraverso il recupero di alcuni concetti tradizionali, una rivendicazione della propria specificità non solo culturale ma anche sociale, una reinterpretazione di alcune dottrine del common law, ma anche un'apertura a più modelli, cercando di imitare con libertà le soluzioni che si presentassero utili per lo sviluppo socio-giuridico della nuova India». Fr ANCAVILLA, Il modello giuridico italiano in India, pp. 430-431.
} 
Constitution of India,${ }^{24}$ adottata dall'Assemblea Costituente Indiana, il 26 novembre 1949, ed entrata in vigore, il 26 gennaio 1950. Tale Costituzione viene affiancata da leggi statutarie, già "codificate" dagli inglesi ed emendate dopo l'indipendenza, e inoltre da nuove leggi approvate dal parlamento indiano nel corso degli ultimi decenni. Non si può dimenticare la "precedenza", che in giurisprudenza viene riconosciuta solo alla Corte Suprema (art. 141 della Costituzione indiana). ${ }^{25}$ L'India si avvale anche di leggi personali attinenti alcuni settori di diritto solo per gli indù o per i mussulmani o per i cristiani. In India sono in vigore anche leggi consuetudinarie di qualche casta o tribù (artt. 13(3)a, 371A, 371G della Costituzione indiana). Così l'attuale cultura giuridica indiana porta in sé la ricchezza di numerosi secoli di storia e l'enorme sua varietà culturale.

\subsection{Cultura ecclesiale indiana}

Parlando della storia della Chiesa in India, Giovanni Paolo II affermava, «le origini della vostra Chiesa sono collegate direttamente agli albori della cristianità e all'impegno missionario degli Apostoli», specialmente San Tommaso. Merita quindi cogliere alcuni momenti significativi della presenza e della crescita della Chiesa in India. ${ }^{26}$

\footnotetext{
${ }^{24} \mathrm{La}$ costituzione indiana, la più lunga del mondo, determina principalmente i seguenti aspetti della "Union": i fondamentali diritti e doveri dei cittadini; i principi direttivi della politica statale; la struttura gerarchica della repubblica e del governo e le procedure da adottare nel suo funzionamento; gli organi giudiziari al livello sia federale sia statale; le strutture interne allo Stato; alcuni ambiti speciali dell'agire della repubblica; le elezioni; altri provvedimenti speciali, ecc.

${ }^{25}$ The Constitution of India, art. 141: «The law declared by the Supreme Court shall be binding on all courts within the territory of India».

${ }^{26}$ Cf. Paul Pallath, The Catholic Church in India, OIRSI, Kottayam 2010; George Nedungatt, Una nuova era per la Chiesa in India, in La civiltà cattolica 140 (1989) pp. 130-144; C E. Aвraham, Rise and Growth of Christianity in India, in: Haridas Bhattacharyya (Ed.), The Cultural Heritage of India, Volume IV. The Religion, The Ramakrishna Mission - Institute of Culture, Calcutta, 1956, pp. 547-570.
} 


\subsubsection{Origini apostoliche}

Oltre alla missione di san Bartolomeo soprattutto nel nord dell'In$\mathrm{dia},{ }^{27}$ la tradizione cattolica, sostenuta da varie fonti ecclesiastiche, indicava l'arrivo a Kodungallur (nel 52 d.C.) di san Tommaso apostolo, il quale dopo aver fondato le «sette Chiese» (Ezharapallikal), venne martirizzato nel luogo dell'attuale monte di San Tommaso a Chennai e sepolto a Mylapore, dove ora sorge la basilica di San Tommaso, la Cattedrale di Madras-Mylapore, India. ${ }^{28}$

\subsubsection{Connessione siriaca e caldea}

Nell'anno 345 giungeva a Kodungallur in India Tommaso il Cananeo, un giudeo-cristiano di fede nestoriana. Dal sec. IV (dopo il Concilio ecumenico di Nicea del 345) fino al sec. XV, si formava così la Chiesa siro-orientale, con vescovi della Chiesa assira d'Oriente dotata del rito liturgico siro-orientale o caldeo. ${ }^{29}$ In effetti, a metà del sec. VII, il Patriarca Ishoyahb III consolidava la gerarchia della Chiesa indiana, diventandone di fatto il capo. Di conseguenza, «avendo accettato i vescovi siro-orientali come propri al tempo della crisi nella Chiesa indiana, i cristiani di san Tommaso accettarono anche i loro libri liturgici siriaci e la loro disciplina canonica. Per il loro uso del siriaco, essi furono chiamati "cristiani siriaci" dai missionari latini». ${ }^{30}$

\subsubsection{Inizio del Padroado portoghese}

La Chiesa latina giungeva in India nel 1321 con i missionari francescani guidati da Tommaso da Tolentino, e nel 1329 viene già eretta la diocesi di Quilon. Nel 1452, Papa Nicolò V determinava i diritti del Padroado portoghese, al quale veniva affidata anche l'India. ${ }^{31} \mathrm{La}$ creazione della diocesi di Goa da parte di Papa Paolo III avverrà nel

\footnotetext{
${ }^{27}$ Cf. Francis Correa, Mother Church in Mother India. Growth of the Catholic Church in India, St. Pauls, Mumbai 2008, pp. 24-29.

${ }^{28}$ Cf. Pallath, The Catholic Church in India, pp. 5-14; Correa, Mother Church in Mother India. Growth of the Catholic Church in India, pp. 18-23.

${ }^{29}$ Cf. Pallath, The Catholic Church in India, pp. 15-21.

${ }^{30}$ Nedungatt, Una nuova era per la Chiesa in India, pp. 132-133.

${ }^{31}$ Cf. Pallath, The Catholic Church in India, pp. 51-61.
} 
1534. In seguito sono state create la diocesi di Cochin nel 1558 e quella di Mylapore nel 1606.

Avendo scoperto espressioni tipicamente duofisite (nestoriane) in alcuni libri siriaci usati dai "cristiani siriaci", nel giugno 1599 l'arcivescovo di Goa, Alexis de Menezes, convocava il Sinodo dei vescovi (il cosiddetto «Sinodo di Diamper») per sancire l'unione dei cristiani di San Tommaso con la Chiesa di Roma. ${ }^{32}$ Da tale unione prendeva forma la Chiesa cattolica siro-malabarese. In seguito, «la lotta dei cristiani di san Tommaso per mantenere l'identità e l'autonomia della propria Chiesa locale, in piena sottomissione al papa, esplose in una rivolta chiamata Coonan Cross Oath (1653). Lacerati da istanze opposte, essi persero la propria unità. La fedeltà al papa richiedeva l'accettazione dei vescovi latini. Ma, secondo alcuni, la perdita dell'identità era un prezzo troppo alto da pagare, tanto che un gruppo aderì al rito siriaco occidentale, cioè a quello della Chiesa giacobita di Antiochia. Esso fu suddiviso ulteriormente dalle vicissitudini della storia. Oggi ci sono circa sette Chiese non cattoliche tra i cristiani di san Tommaso. Nel 1930 un gruppo giacobita si riunì alla Chiesa cattolica: è l'attuale Chiesa cattolica siro-malankarese». ${ }^{33}$

\subsubsection{Interventi della Congregazione de Propaganda Fide}

Nel 1622, venne creata la Congregazione de Propaganda Fide con la giurisdizione su tutti i territori missionari. Con l'erezione del vicariato apostolico a Bijapur nel 1637 da parte della Congregazione, inizia una lunga "battaglia" tra il Padroado e la Congregazione de Propaganda Fide. ${ }^{34} \mathrm{Nel}$ corso dei secoli passati, la Congregazione erigeva altri vicariati apostolici a Verapoly (1700), Madras (1832), Bengal (1834) e Coramandel (1834). Nel 1838, in seguito alla rottura della relazione

\footnotetext{
${ }^{32}$ Cf. Pallath, The Catholic Church in India, pp. 90-111.

${ }^{33}$ Nedungatt, Una nuova era per la Chiesa in India, pp. 133-134. Cf. Pallath, The Catholic Church in India, pp. 112-118.

${ }^{34}$ Cf. Pallath, The Catholic Church in India, pp. 62-81; Cosme Jose Costa, A Missiological Conflict between Padroado and Propaganda in the East, Pilar Publications, Goa 1997, pp. 45-74.
} 
diplomatica tra Portogallo e Santa Sede del 1833, avvenne la soppressione della giurisdizione del Padroado in India, eccettuata Goa. Dopo il nuovo concordato tra Portogallo e Santa Sede del 1886, Papa Leone XIII stabiliva la nuova gerarchia latina, con 6 province ecclesiastiche latine in India. Finalmente, con il nuovo concordato tra Portogallo e Santa Sede del 1950, ovvero dopo l'indipendenza dell'India, viene sancita in modo definitivo la rinuncia dei diritti del Padroado in India.

\subsubsection{Realtà attuale della Chiesa cattolica}

L'attuale configurazione delle 3 Chiese cattoliche sui iuris in India comprende 168 diocesi, con 23 Province ecclesiastiche di rito latino, 5 Province ecclesiastiche siro-malabaresi e 2 Province ecclesiastiche siro-malankaresi. La storia della Chiesa in India può essere così sintetizzata usando le recenti parole di Papa Francesco: «Fra le terre e le nazioni, nelle quali questa varietà della vita ecclesiale rifulge con grande splendore vi è anche l'India. La Chiesa cattolica in India trae la sua origine dalla predicazione dell'Apostolo Tommaso, si è sviluppata attraverso i contatti con le Chiese di tradizione caldea e antiochena e, a partire dal XVI secolo, grazie agli sforzi dei missionari latini. In questo modo la storia del cristianesimo in questo grande Paese ha portato infine alla configurazione di tre distinte Chiese sui iuris, che corrispondono ad espressioni ecclesiali della medesima fede celebrata in riti diversi corrispondenti alle tre tradizioni liturgiche, spirituali, teologiche e disciplinari. Anche se questa situazione nel corso della storia ha manifestato a volte alcune tensioni, oggi possiamo ammirare una realtà cristiana ricca e bella, complessa e unica allo stesso tempo». ${ }^{35}$

\section{Alcune sfide attuali}

Partendo dalla breve lettura storica delle realtà culturali ed ecclesiali in India, si possono ora sottolineare alcune sfide emergenti nella società sia civile che ecclesiale.

\footnotetext{
${ }^{35}$ Francesco, Lettera La mirabile varietas Ecclesiarum ai vescovi dell'India, 9 ottobre 2017, in http://w2.vatican.va/content/francesco/it/letters/2017/documents/ papa-francesco_20171009_vescovi-india.html\#_ftn7 (consultato il 24 ottobre 2018).
} 


\subsection{Nella società civile}

L'India, essendo una «Sovereign Socialist Secular Democratic Republic» (The Constitutions of India, Preamble), riconosce l'uguaglianza di diritti a tutti i suoi cittadini senza alcuna discriminazione soprattutto in base alla religione di appartenenza. ${ }^{36}$ Nella legislazione indiana, oltre al riconoscimento legale della Chiesa, sono rilevabili alcune implicazioni attinenti questioni che toccano la Chiesa e i suoi membri.

\subsubsection{Riconoscimento legale della Chiesa}

La religione viene definita, in una sentenza della Corte Suprema dell'India, come un gruppo di fedeli con una fede comune, un'organizzazione comune e un nome distinto. ${ }^{37}$ Partendo da questa definizione, si tenta qui di individuare sia i tratti del riconoscimento legale della Chiesa e le sue componenti sia l'applicazione della legislazione indiana alla realtà ecclesiale.

\section{a. Riconoscimento civile e status}

La Chiesa viene vista come una associazione volontaria di individui, i cui diritti vengono protetti dai rispettivi statuti e inoltre dalle legislazioni indiane in quanto organo civilmente riconosciuto. ${ }^{38} \mathrm{Per}$

\footnotetext{
${ }^{36}$ Infatti, il diritto all'uguaglianza viene trattato dalla Costituzione indiana come la parità legale e uguale protezione legale di tutti (art. 14); divieto di discriminazione per motivi di religione, razza, casta, sesso o luogo di nascita (art. 15); e parità di opportunità in materia di lavori/uffici pubblici (art. 16).

${ }^{37}$ "The words "religious denomination" in Art. 26 of the Constitution must take their colour from the word "religion" and if this be so, the expression "religious denomination" must also satisfy three conditions: (1) It must be a collection of individuals who have a system of beliefs or doctrines which they regard as conducive to their spiritual well-being, that is, a common faith; (2) common organisation; and (3) designation by a distinctive name». Acharya Jagdishwaranand Avadhuta, Etc. vs Commissioner of Police, Calcutta \& Anr., 20 October 1983, 1984 SCR (1) 447, in https://indiankanoon.org/doc/798012/ (consultato il 02 novembre 2018).

${ }^{38}$ «A church is formed by the voluntary association of individuals. And the churches in the commonwealth are voluntary body organised on a consensual basis their rights apart from statutes will be protected by the courts and their discipline enforced exactly as in the case of any other voluntary body whose existence is legally
} 
il riconoscimento della personalità giuridica della Chiesa, e di altri enti ecclesiastici (come diocesi, parrocchie, case religiose, ecc.), se ne richiede la costituzione e registrazione sotto il The Societies Registration Act, $1860,{ }^{39}$ qualora si intenda creare una "società" per le attività caritatevoli o religiose, o sotto il The Indian Trusts Act, $1882,{ }^{40}$ nel caso di una "fondazione". Tale registrazione poi non solo assicura la personalità giuridica, ma anche determina le regole da seguire quanto ai membri e al comitato esecutivo, ai diritti e doveri dei membri e della società, alla proprietà e al suo uso, ecc.

\section{b. Leggi personali cristiane (Personal law)}

Come per gli indù ${ }^{41}$ e i mussulmani, ${ }^{42}$ così anche per i cristiani sono previste alcune leggi personali applicabili soltanto a loro. ${ }^{43} \mathrm{Si}$ possono individuare tre ambiti della loro applicazione. Il matrimonio cristiano indiano e il suo scioglimento civile vengono regolati dal The Indian Christian Marriage Act, 1872, e dal The Special Marriage Act, 1954. Per la successione ed eredità nel caso dei cristiani, si segue il The Indian Succession Act, 1925, in quanto esso "non (è) applicabile agli indù e ai mussulmani". Nell'ambito della adozione e tutela (tutori), si applica il The Guardians and Wards Act, 1890, che permetteva solo la tutela dei minori da parte dei tutori cristiani. I cristiani non potevano

recognised». Most. Rev. P.M.A. Metropolitan \& Ors. vs Moran Mar Marthoma \& Anr., 20 June 1995, 1995 SCC Supl. (4) 286, in https://indiankanoon.org/doc/634316/ (consultato il 03 novembre 2018).

${ }^{39}$ Cf. The Societies Registration Act, 1860, Act No. 21 of 1860 (21 May 1860), in https://indiankanoon.org/doc/1700055/ (consultato il 04 novembre 2018).

${ }^{40}$ Cf. The Indian Trusts Act, 1882, Act No. 2 of 1882 (13 January 1882), in https:// indiankanoon.org/doc/470004/ (consultato il 04 novembre 2018).

${ }^{41}$ Per gli indù, si applicano: The Hindu Marriage Act, 1955; The Hindu Succession Act, 1956 (amended 2005); The Hindu Minority \& Guardianship Act, 1956; e The Hindu Adoptions \& Maintenance Act, 1956.

${ }^{42}$ Per i mussulmani, si applicano: The Muslim Personal Law (Shariat) Application Act, 1937 (con cui la sharia viene applicate ai mussulmani); e The Dissolution of Muslim Marriages Act, 1939.

${ }^{43}$ Cf. Meher K. Master, Personal Laws of Religious Communities in India, in Journal of Dharma 11 (1986) pp. 266-277. 
adottare, se non per intervento della Corte. Attualmente i cristiani possono adottare legalmente seguendo il The Juvenile Justice (Care and Protection of Children) Act, 2015 (sez. 56-68).

Ecco una seria domanda su un altro aspetto importante: può il diritto canonico essere considerato come la "legge personale" per i cattolici in India? Applicando la sez. 88 del The Indian Christian Marriage Act, 1872, la Corte Suprema ha dichiarato che il Codex Iuris Canonici possa essere considerato come "legge personale" per cattolici in India, nei casi (aspetti del matrimonio) previsti dalla legge. ${ }^{44}$

Per quanto riguarda il riconoscimento dei tribunali ecclesiastici e processi canonici, si può confermare che né tribunali ecclesiastici né processi canonici (soprattutto quelli matrimoniali), tanto meno i loro pronunciamenti, vengono riconosciuti dallo Stato indiano. ${ }^{45}$ Però le decisioni ecclesiastiche possono essere presentate come una "evidenza" nella corte civile, soprattutto in vista dello scioglimento del matrimonio, cioè per dichiarare matrimoni nulli o annullabili, o per proseguire il divorzio. ${ }^{46}$

\section{c. Legislazione sulla "minoranza"}

La legislazione sulla "minoranza" viene trattata nella Costituzione indiana agli articoli 29-30. ${ }^{47}$ Tale legislazione è applicabile anche ai

\footnotetext{
${ }^{44}$ «The question of capacity to marry and impediments in the way of marriage would have to be resolved by referring to their personal law. That, for the purpose of deciding the validity of the marriage, would be the law of the Roman Catholic Church, namely, the Canon law of that Church». Lakshmi Sanyal vs Sachit Kumar Dhar, 8 September 1972, 1973 SCR (2) 122, in https://indiankanoon.org/doc/734017/ (consultato il 04 novembre 2018). Cf. Sahayaraj Lourdusamy, Church Related Issues and the Civil Courts of India, St. Pauls, Mumbai 2015, pp. 88-91; SAHAYARAJ Lourdusamy, Handbook on the Civil Cases Concerning the Catholic Church in India, St. Pauls, Mumbai 2016, pp. 32-36.

${ }^{45}$ Cf. Lourdusamy, Handbook on the Civil Cases Concerning the Catholic Church in India, pp. 38-40.

${ }^{46}$ Cf. Lourdusamy, Church Related Issues and the Civil Courts of India, p. 91.

${ }^{47}$ Cf. Amit Kumar Ishwar Bhai Parmar, Protection of the Interests of Minority under the Indian Constitution, in International Journal of Novel Research in Interdisciplinary Studies 2/4 (2015) pp. 27-33.
} 
cristiani in quanto "minoranza religiosa" in India. L'art. 29 tratta della protezione degli interessi delle minoranze in base alla religione, alla lingua o alla cultura. Ciò implica il diritto di conservare la loro lingua, scrittura e cultura. Dunque, non ci può essere nessuna discriminazione per l'ammissione negli istituti educativi in base alla religione, alla razza, alla casta o alla lingua. L'art. 30 tratta del diritto delle minoranze a istituire e amministrare le istituzioni educative. Ciò si traduce nel diritto delle minoranze linguistiche o religiose a istituire e amministrare le istituzioni educative di loro scelta. Implica anche che non sia contro questo diritto qualunque acquisizione obbligatoria (da parte dello Stato) di qualsiasi proprietà dell'istituzione educativa amministrata da una minoranza e, di conseguenza, tali istituzioni non vanno discriminate quando si tratta di assegnare loro aiuti statali.

\subsubsection{Alcune implicazioni legislative}

L'applicazione della legislazione indiana nei confronti della Chiesa e dei cristiani comporta implicazioni su alcune questioni importanti presentate di seguito.

\section{a. Questione della libertà religiosa}

La Costituzione indiana enumera gli aspetti del diritto della libertà religiosa: libertà di coscienza e libera professione, pratica e propagazione della religione (art. 25); libertà di gestione degli affari religiosi con istituzioni religiose e caritative, avendo il diritto di possedere e acquisire beni mobili e immobili e di amministrare tale proprietà secondo la legge (art. 26); libertà circa l'esenzione dal pagare le tasse per la promozione di qualsiasi religione particolare (art. 27); libertà di partecipazione all'istruzione religiosa o ad un culto religioso in alcune istituzioni educative (art. 28). La Corte Suprema ha di fatto determinato l'applicazione pratica dei suindicati diritti: diritto a determinare la dottrina e la prassi della religione; diritto alla libertà di religione, sottoposto ai limiti dell'ordine pubblico, della moralità e di sanità; diritto alla libertà di gestione degli affari religiosi, la quale include anche la possibilità di scomunica di un membro; vari diritti circa attività religiose esterne come diritto alla processione religiosa 
e all'uso degli altoparlanti (con permessi e non contro l'ordine pubblico), diritto alla preghiera nelle case private, dovere dello Stato di riparare luoghi sacri distrutti a causa di qualche disordine pubblico a sfondo religioso, ecc.

Non si può dimenticare la questione delle legislazioni anti-conversione presenti in vari Stati dell'India che sono in contrasto con il principio della libertà di propagazione della religione sancita dall'art. 25 della Costituzione indiana. Infatti, tali legislazioni regionali contro la conversione religiosa, ${ }^{48}$ sono entrate in vigore con la cosiddetta "Freedom of Religion Act" negli Stati di Orissa (1967), Madhya Pradesh (1968), Arunachal Pradesh (1978), Chhattisgarh (2000), Gujarat (2003), Himachal Pradesh (2007), Rajasthan (2008); e Tamil Nadu (2002 e poi ritirata). Queste leggi cercano di impedire sia la conversione o il tentativo di conversione di qualunque persona, direttamente o indirettamente, attraverso la violenza, il timore grave o l'inganno, sia di indurre oppure attirare inopportunamente qualcuno a un'altra religione. ${ }^{49}$ Nonostante vari tentativi di appelli contro tale legislazione, la Corte Suprema ha sempre affermato che tale legislazione degli Stati sono da considerare parte di sua competenza in quanto essa promuove e difende l'ordine pubblico e in quanto la libertà di propagazione della propria religione non include il "diritto di conversione" di un altro. ${ }^{50}$

\footnotetext{
${ }^{48}$ Cf. Lourdusamy, Handbook on the Civil Cases Concerning the Catholic Church in India, pp. 53-57; LourdusAmy, Church Related Issues and the Civil Courts of India, pp. 134-141; Alliance for Justice \& Accountability, Minority Rights Violations in India, Washington, D.C. 2017, pp. 44-45.

${ }^{49}$ Ciò sembra molto simile al can. $748 \$ 2$ e al CCEO Can. 586: «È severamente proibito costringere o indurre con inopportuni raggiri oppure attirare qualcuno ad abbracciare la Chiesa; tutti i fedeli cristiani, invece, si impegnino affinché sia rivendicato il diritto alla libertà religiosa e che nessuno con ingiuste vessazioni sia distolto dalla Chiesa».

${ }^{50}$ "We have no doubt that it is in this sense that the word "propagate" has been used in Article 25 (1), for what the Article grants is not the right to convert another person to one's own religion, but to transmit or spread one's religion by an exposition of its tenets. It has to be remembered that Article 25 (1) guarantees "freedom of conscience" to every citizen, and not merely to the followers of one particular religion, and that, in turn, postulates that there is no fundamental right to convert
} 
Negli ultimi anni, però, è cresciuta una contra-tendenza che vede i fondamentalisti indù "riconvertire" all'induismo coloro che un tempo s'erano convertiti al cristianesimo, con il cosiddetto "Programma Ghar Wapsi”. Sia il governo sia la Corte Suprema non sono intervenuti ufficialmente su questo fenomeno, che ha suscitato intimidazione e paura tra i cristiani. ${ }^{51}$

Ė molto grave la questione dei cristiani dalit, che perdono tutti i loro privilegi dopo la "conversione" alla fede cristiana. Siccome, dopo la conversione non sono considerati più dalit, secondo l'ordine presidenziale del 1950, perdono anche la protezione legale prevista dal The Scheduled Castes and the Scheduled Tribes (Prevention of Atrocities) Act, $1989 .{ }^{52}$ Inoltre, secondo la Corte Suprema, la situazione dei cristiani dalit non è stata dimostrata così difficile e degradante se confrontata con quella dei dalit appartenenti alle altre religioni. ${ }^{53}$

another person to one's own religion because if a person purposely undertakes the conversion of another person to his religion, as distinguished from his effort to transmit or spread the tenets of his religion, that would impinge on the "freedom of conscience" guaranteed to all the citizens of the country alike». Rev. Stainislaus vs State of Madhya Pradesh \& Ors., 17 January 1977, 1977 SCR (2) 611, in https:// indiankanoon.org/doc/1308071/ (consultato il 03 novembre 2018).

${ }^{51}$ Cf. Alliance for Justice \& Accountability, Minority Rights Violations in India, p. 42.

${ }^{52}$ Cf. The Scheduled Castes and the Scheduled Tribes (Prevention of Atrocities) Act, 1989, Act No. 33 of 1989 (11 September 1989), in https://indiankanoon.org/ doc/25085007/ (consultato il 27 novembre 2018); The Scheduled Castes and the Scheduled Tribes (Prevention of Atrocities) Amendment Act, 2015, Act No. 1 of 2016 (31 December, 2015), in http://www.indiacode.nic.in/acts-in-pdf/2016/201601.pdf (consultato il 27 novembre 2018).

${ }^{53}$ «To establish that paragraph 3 of the Constitution (Scheduled Castes) Order, 1950 discriminates against Christian members of the enumerated castes, it must be shown that they suffer from a comparable depth of social and economic disabilities and cultural and educational backwardness and similar levels of degradation within the Christian community necessitating intervention by the State under the provisions of the Constitution. It is not sufficient to show that the same caste continues after conversion. It is necessary to establish further that the disabilities and handicaps suffered from such caste membership in the social order of its origin Hinduism continue in their oppressive severity in the new environment of a different religious 
Queste difficoltà sembrano vanificare l'affermato diritto costituzionale della libertà religiosa.

\section{b. Matrimonio "cristiano" indiano e il suo scioglimento civile}

Per il matrimonio in ambito civile tra cristiani o dove almeno una parte è cristiana, si segue The Indian Christian Marriage Act, $1872 .{ }^{54}$ Questa legge richiede che il matrimonio avvenga davanti al ministro cristiano e con due testimoni (sez. 25) e che sia registrato l'avvenuto matrimonio seguendo la prassi della Chiesa, anche quella cattolica (sez.30). Va notato che non può rendere valido un matrimonio che le leggi personali delle parti coinvolte proibiscono (sez. 88). Tale proibizione viene applicata, secondo la Corte Suprema, solo agli impedimenti matrimoniali e non alla forma o al ministro del matrimonio. ${ }^{55}$

Per il matrimonio civile tra cristiani o una parte cristiana, si può anche seguire The Special Marriage Act, $1954 .{ }^{56}$ Questa legislazione indica anche le condizioni per il matrimonio (sez. 5: non sposato/a attualmente, capace di consenso, l'età minima e relazioni consanguinee proibite), per i matrimoni nulli (sez. 24: le condizioni indicate sopra, oltre all'impotenza), per i matrimoni annullabili (sez. 25: matrimonio non consumato, aspettativa o avere figli da un'altra persona, matrimonio celebrato con violenza o dolo), inoltre per la separazione (sez. 23) e per il divorzio (sez. 27). Occorre sottolineare la non reciprocità dello scioglimento del matrimonio tra la Chiesa e lo Stato, per cui lo scioglimento determinato dal tribunale ecclesiastico non viene riconosciuto dallo Stato, così come quello stabilito dal tribunale civile

community». Soosai Etc. vs Union of India and Others, 30 September 1985, 1985 SCR Supl. (3) 242, in https://indiankanoon.org/doc/1724190/ (consultato il 02 novembre 2018).

${ }^{54}$ Cf. The Indian Christian Marriage Act, 1872, Act No. 15 of 1872 (18 July 1872), in https://indiankanoon.org/doc/1166543/ (consultato il 28 novembre 2018).

${ }^{55}$ Cf. Lourdusamy, Handbook on the Civil Cases Concerning the Catholic Church in India, pp. 32-35; Lourdusamy, Church Related Issues and the Civil Courts of India, pp. 206-208.

${ }^{56}$ Cf. The Special Marriage Act, 1954, Act No. 43 of 1954 (9 October 1954), in https:// indiankanoon.org/doc/4234/ (consultato il 28 novembre 2018). 
non viene accolto nella Chiesa. Anche in questi casi, è chiaro che in materia di matrimonio e suo scioglimento non tutto è compatibile tra il diritto civile e il diritto canonico.

\section{c. Ambito dell'apostolato, specialmente dell'educazione}

La Chiesa di fatto ha offerto un grande contribuito all'India attraverso il suo apostolato, specialmente in ambito educativo. La Costituzione indiana stabilisce anche il fondamento di tale possibilità all'art. 30, dove viene affermato il diritto delle minoranze di stabilire e amministrare le istituzioni educative. La Corte Suprema ha interpretato il diritto di stabilire le istituzioni educative, come parte dei diritti speciali di minoranze religiose di promuovere l'educazione e di avere le istituzioni educative, e i diritti all'educazione religiosa, stabilendo una distinzione tra educazione religiosa e istruzione religiosa. Anche il diritto di amministrare le istituzioni educative è stato interpretato in vari diritti: diritto di scegliere i dirigenti scolastici, gli insegnanti e il personale non docente; diritto circa l'ammissione all'istituzione educativa; diritto alla proprietà delle istituzioni educative; diritto all'aiuto dello Stato all'istituzione educativa; e dovere di regolamentare l'educazione impartita entro il quadro determinato dallo Stato. ${ }^{57}$ Questi diritti hanno senz'altro aiutato positivamente la Chiesa e il suo apostolato educativo in India.

d. Competenze del foro civile sulle questioni ecclesiastico-canoniche

Nel caso del foro civile, sono previste delle competenze su questioni ecclesiastico-canoniche? La risposta si può trovare nel The Code of Civil Procedure, $1908,{ }^{58}$ che nella sez. 9 definisce la giurisdizione civile

\footnotetext{
${ }^{57}$ Cf. Lourdusamy, Handbook on the Civil Cases Concerning the Catholic Church in India, pp. 103-130; Lourdusamy, Church Related Issues and the Civil Courts of India, pp. 257-281.

58 «Courts to try all civil suits unless barred: The Courts shall (subject to the provisions herein contained) have jurisdiction to try all suits of a civil nature excepting suits of which their cognizance is either expressly or impliedly barred. [Explanation I]. A suit in which the right to property or to an office is contested is a suit of a civil nature, notwithstanding that such right may depend entirely on
} 
sul diritto alla proprietà e all'ufficio, anche se basata principalmente sulle questioni di riti religiosi. Stando all' interpretazione dalla Corte Suprema, è chiara la mancanza di competenza del foro civile sul credo, sulle pratiche religiose, sulla disciplina interna, sulla nomina e sui trasferimenti dei ministri. Tuttavia, il foro civile può giudicare sulle cose spirituali o rituali della Chiesa, se hanno incidenza o pertinenza temporale, come l'amministrazione, i luoghi sacri, i privilegi o la discriminazione delle caste. ${ }^{59}$

\subsection{Nella Chiesa}

Si rilevano ora alcune sfide che l'attuale situazione ecclesiale deve affrontare nella realtà indiana: i modi di adattamento del diritto canonico nelle Chiese in India; il difficile rapporto tra le Chiese sui iuris; l'impegno per l'uguaglianza nella Chiesa; e la necessità di inculturazione e di dialogo inter-religioso ed ecumenico in India oggi.

\subsubsection{Adattamento del diritto canonico}

Il diritto canonico, nel suo percorso storico e nella sua situazione attuale, ha dovuto adattarsi alle realtà ecclesiali indiane in vari modi: accogliendo prima le competenze speciali della Congregazione dell'Evangelizzazione dei Popoli per tutto il territorio indiano, poi le competenze speciali della Congregazione per le Chiese Orientali per quanto riguarda le Chiese orientali sui iuris e infine le leggi complementari della Conferenza Episcopale dell'India. Il sovrapporsi delle normative non è sempre stato facile da gestire e da applicare nei contesti di evangelizzazione e di governo della Chiesa in India.

the decision of questions as to religious rites or ceremonies. [Explanation II]. For the purposes of this section, it is immaterial whether or not any fees are attached to the office referred to in Explanation I or whether or not such office is attached to a particular place». The Code of Civil Procedure, 1908, Act No. 5 of 1908 (21 March 1908), in http://www.wipo.int/edocs/lexdocs/laws/en/in/in056en.pdf (consultato il 19 ottobre 2018).

${ }^{59}$ Cf. Lourdusamy, Handbook on the Civil Cases Concerning the Catholic Church in India, pp. 19-31; LourdusAmy, Church Related Issues and the Civil Courts of India, pp. 97-110, 118. 


\section{a. Competenze della Congregazione dell'Evangelizzazione dei Popoli e il diritto missionario}

Prima di tutto, essendo l'India considerata ancora un territorio missionario, non ci si può dimenticare delle seguenti competenze della Congregazione dell'Evangelizzazione dei Popoli verso i territori missionari (Pastor Bonus 85-92): ${ }^{60}$ dirigere e coordinare in tutto il mondo l'opera stessa dell'evangelizzazione dei popoli e la cooperazione missionaria (art. 85); promuovere le ricerche di teologia, di spiritualità e di pastorale missionaria e proporre le norme e le linee di azione, adattate alle esigenze dei tempi e dei luoghi (art. 86); far collaborare efficacemente il Popolo di Dio all'opera missionaria (art. 87); suscitare le vocazioni missionarie e curare la formazione del clero secolare e dei catechisti (art. 88); assicurare l'evangelizzazione attraverso gli idonei istituti e società, erigere e modificare le circoscrizioni ecclesiastiche e assolvere tutti i compiti della Congregazione per i Vescovi (art. 89); avere competenze sugli istituti di vita consacrata e sulle società di vita apostolica, eretti nei territori di missione oppure ivi operanti (art. 90); incrementare la cooperazione missionaria, con l'aiuto delle Pontificie Opere Missionarie (art. 91) e amministrare il proprio patrimonio e gli altri beni destinati alle missioni mediante un suo speciale ufficio (art. 92).

Oltre alle suddette competenze speciali, si applicano anche le facoltà speciali concesse dalla Sede Apostolica per i territori missionari, soprattutto quelle enunciate dal Papa Benedetto XVI nel 2005 e nel 2008, sui seguenti ambiti: ${ }^{61}$ la rinuncia dei vescovi, le nomine dei prefetti apostolici, le modifiche dei territori delle Chiese particolari, il numero di celebrazioni eucaristiche che sacerdoti possono presiedere ogni giorno, la dispensa dell'età per l'ordinazione, l'assistenza

\footnotetext{
${ }^{60}$ Cf. Giovanni Paolo II, Costituzione Apostolica Pastor Bonus sulla Curia Romana, 28 giugno 1988, nn. 85-92, in http://w2.vatican.va/content/john-paul-ii/ it/apost_constitutions/documents/hf_jp-ii_apc_19880628_pastor-bonus-index. html (consultato il 10 dicembre 2018).

${ }^{61}$ Cf. Fernando Filoni, The Reception of the Code in the Missionary Territories and the Special Faculties Granted to the Congregation for the Evangelization of Peoples, in The Jurist 76 (2016) pp. 5-18.
} 
al matrimonio da parte dei laici, la recognitio degli statuti e delle normative delle Conferenze Episcopali, la riduzione delle messe pro populo, e la dimissione dallo stato clericale in poenam.

\section{b. Diritto canonico orientale e competenze della Congregazione per le Chiese Orientali}

Non si possono disattendere inoltre le Chiese orientali sui iuris presenti in India: la Chiesa cattolica siro-malabarese e la Chiesa cattolica siro-malankarese. Essendo appunto Chiese orientali sui iuris, queste Chiese seguono lo ius commune determinato nel Codex Canonum Ecclesiarum Orientalium. Sono vincolate anche dal diritto particolare della propria Chiesa, enunciato dai suoi organi legislativi, cioè il loro Sinodo dei vescovi (CCEO cann. $110 \$ 1,150 \$ 2,152)$.

Occorre ricordare inoltre le competenze speciali della Congregazione per le Chiese Orientali verso le Chiese orientali cattoliche sui iuris (Pastor Bonus 56-61) elencate qui di seguito: trattare tutte le materie concernenti le Chiese orientali, circa le persone e le cose (art. 56); avere la competenza su tutti gli affari, che sono propri delle Chiese orientali, specialmente su: la struttura e l'ordinamento delle Chiese, l'esercizio delle funzioni di insegnare, di santificare e di governare, le persone, il loro stato, i loro diritti e doveri (art. 58); seguire con premurosa diligenza le comunità di fedeli orientali che si trovano nelle circoscrizioni territoriali della Chiesa latina (art. 59); svolgere l'azione apostolica e missionaria nelle regioni "orientali" (art. 60); e promuovere il dialogo ecumenico e il dialogo interreligioso, con l'intesa dei dicasteri competenti della Curia romana (art. 61). Anche quando le competenze sono chiare, la loro applicazione pratica non è sempre facile.

\section{c. Conferenze Episcopali Indiane e Diritto particolare}

Dalla sua fondazione nel 1944, la Catholic Bishops' Conference of India $(C B C I),{ }^{62}$ ovvero l'Associazione permanente dei vescovi cat-

\footnotetext{
${ }^{62}$ Le informazioni sono state prese dal sito-web ufficiale della CBCI: http://cbci. in/about_us.aspx (consultato il 06 dicembre 2018).
} 
tolici in India, si presenta come «il volto della Chiesa cattolica in India», al servizio delle 168 diocesi, di cui 131 Latine, 29 Siro-malabaresi e 8 Siro-malankaresi, raggruppate in 30 province ecclesiastiche. Attualmente la $C B C I$ tratta solo le «questioni di interesse comune e di carattere nazionale e sopra-rituale».

In seguito alla Lettera di Papa Giovanni Paolo II (1987) a tutti i vescovi dell'India, sono state istituite tre "Conferenze Episcopali" con i propri diritti e la corrispondente legislazione ecclesiastica, cioè una per ogni Chiesa sui iuris: Conference of the Catholic Bishops of India (CCBI) per la Chiesa latina, Syro-Malabar Bishops' Synod (SMBS) per la Chiesa Siro-malabarese e Holy Episcopal Synod per la Chiesa Siro-malankarese. Oltre a questa diversità di "conferenze episcopali", ci sono anche 14 "conferenze episcopali" regionali, chiamate "Regional Bishops' Councils".

La Conference of the Catholic Bishops of India (CCBI) ha adottato la normativa complementare al CIC per la Chiesa Latina (Complementary Legislations to the Code of Canon Law), che è entrato in vigore, dopo l'approvazione della Congregazione dell'Evangelizzazione dei Popoli, il 16 aprile $1995 .{ }^{63}$ Inoltre, occorre ricordare il diritto particolare delle Chiese Siro-malabarese e Siro-malankarese, emanato dai rispettivi Sinodi dei vescovi e promulgato dai loro arcivescovi maggiori (CCEO cann. $110 § 1,150 \S 2,152$ ).

\subsubsection{Rapporto tra le Chiese sui iuris}

La presenza delle tre Chiese sui iuris, cioè Latina, Siro-malabarese e Siro-malankarese, è una grande ricchezza per la Chiesa cattolica in India. Ci sono, tuttavia, delle difficoltà nei loro rapporti quanto all'applicazione della varietà di norme ecclesiastiche e nell'ambito della evangelizzazione e della pastorale.

\footnotetext{
${ }^{63}$ Cf. Conference of the Catholic Bishops of India (CCBI), Complementary Legislations to the Code of Canon Law, 16 aprile 1995, in http://ccbi.in/wp-content/ uploads/2015/12/Complementary-Legislations-to-the-Code-of-Canon-Law-1.pdf (consultato il 6 dicembre 2018).
} 


\section{a. Problemi di compatibilità del diritto della Chiesa}

Nei territori ove sono sovrapposte le competenze pastorali latine e orientali verso gli stessi fedeli orientali, tale sovrapposizione crea problemi nell'applicazione della normativa canonica latina e/o orientale in alcuni ambiti e soprattutto in quello sacramentali. La Lettera Apostolica in forma di Motu Proprio di Papa Francesco, De concordia inter Codices, ${ }^{64}$ ha cercato di ovviare alcune incongruenze tra i due Codici della Chiesa universale e ha senzaltro portato chiarezza e coerenza nell'applicazione del diritto della Chiesa. Data la molteplice normativa ecclesiastica di riferimento, la sua applicazione pratica in certi casi non è affatto facile.

\section{b. Questione del territorio e delle competenze pastorali}

Le difficoltà nel rapporto tra le Chiese sui iuris in India riguardano principalmente tre ambiti: la cura pastorale dei fedeli orientali nel territorio latino, l'impegno missionario in India, la giurisdizione "territoriale" delle Chiese sui iuris sull'India.

Per quanto riguarda la cura pastorale dei fedeli orientali e l'impegno missionario, prendendo lo spunto dalla sua Lettera ai Vescovi dell'India del 28 maggio 1987, Giovanni Paolo II invitava i vescovi a superare difficoltà e ostilità: «Sono indispensabili grande disponibilità e comprensione reciproca. La prima forma di comunione è quella che unisce tutti i credenti in Cristo, figli dell'unica Chiesa di Cristo. Bisogna fare ogni cosa in un'atmosfera di fiducia e di finalità comuni, esaminando le varie situazioni con obiettività e cercando di risolverle con uno spirito di sentita collaborazione. Devono essere banditi i conflitti, poiché, il bene non può scaturire che dall'amore». ${ }^{65}$

\footnotetext{
${ }^{64}$ Cf. Francesco, Lettera Apostolica in forma di Motu Proprio De concordia inter Codices, con la quale vengono mutate alcune norme del Codice di Diritto Canonico, 15 settembre 2016, in https://press.vatican.va/content/salastampa/it/bollettino/pubblico/2016/09/15/0646/01457.html\#ital (consultato il 18 novembre 2018).

${ }^{65}$ Giovanni Paolo II, Discorso Oggi il Vescovo di Roma ai vescovi del Sinodo della Chiesa Siro-Malabarese dell'India, 8 gennaio 1996, in https://w2.vatican.va/content/ john-paul-ii/it/speeches/1996/january/documents/hf_jp-ii_spe_19960108_syro-malabar-church.html (consultato il 23 novembre 2018).
} 
Per la cura pastorale dei fedeli orientali da parte dei pastori latini (CIC cann. $372 \$ 2,383 \$ 2,476,518$, CCEO cann. 38, $192 \$ 1,246$, $280 \$ 1,916 \$ \$ 4-5)$, proponeva la seguente soluzione pratica: «Circa la cura pastorale dei fedeli dei Riti orientali che vivono in Diocesi di Rito latino, secondo lo spirito e la lettera dei Decreti conciliari Christus Dominus 23, 3 e Orientalium Ecclesiarum 4, gli Ordinari latini di tali Diocesi devono assicurare al più presto possibile un'adeguata cura pastorale dei fedeli di Rito orientale, attraverso il ministero di sacerdoti o mediante parrocchie del Rito, dove ciò fosse opportuno, o per opera di un Vicario episcopale». ${ }^{66}$

Giovanni Paolo II, inoltre, sottolineava l'importanza dell'impegno missionario di tutti nel contesto indiano: «La Chiesa guarda con viva riconoscenza ed ammirazione all'impegno missionario delle Chiese Orientali in India ed auspica che esso possa estendersi ad altre Chiese, e che tutti sappiano accogliere con gratitudine questa mirabile collaborazione alla crescita del Regno, secondo forme diverse e diverse tradizioni». ${ }^{67}$

La spinosa questione della giurisdizione "territoriale" delle Chiese orientali sui iuris su tutto l'India è stata risolta, almeno parzialmente, per quanto riguarda la Chiesa siro-malabarese, da Papa Francesco, che nella recente lettera ha stabilito: «Pertanto, ho autorizzato la Congregazione per le Chiese Orientali a provvedere alla cura pastorale dei fedeli siro-malabaresi in tutta l'India, attraverso l'erezione di due Eparchie e l'estensione dei confini di due già esistenti. Determino, inoltre, che le nuove come le esistenti circoscrizioni risultino affidate all'Arcivescovo Maggiore di Ernakulam-Angamaly e al Sinodo dei Vescovi della Chiesa Siro-malabarese, a norma del CCEO». ${ }^{68}$

\footnotetext{
${ }^{66}$ Giovanni Paolo II, Discorso È per me ai partecipanti alla plenaria della Congregazione per le Chiese Orientali, $1^{\circ}$ ottobre 1998, in http://m.vatican.va/content/ john-paul-ii/it/speeches/1998/october/documents/hf_jp-ii_spe_19981001_chiese-orientali.html (consultato il 24 novembre 2018).

${ }^{67}$ Ibid.

${ }^{68}$ Francesco, Lettera La mirabile varietas Ecclesiarum ai vescovi dell'India, 9 ottobre 2017. Il corsivo è mio.
} 
Sapendo che la soluzione delle problematiche non è così semplice, Papa Francesco ha invitato tutti i fedeli in India a vivere la comunione e l'amore fraterno: "La via della Chiesa cattolica in India non può essere quella dell'isolamento e della separazione, ma piuttosto del rispetto e della collaborazione. La presenza di diversi Vescovi delle varie Chiese sui iuris nello stesso territorio potrà essere motivo sicuramente di bellissima e vivificante comunione e testimonianza... In questo spirito, esorto tutte le amatissime Chiese che vivono in India alla generosità e al coraggio per la testimonianza del Vangelo in spirito di fraternità e mutuo amore». ${ }^{69}$

Ha suggerito inoltre i passi concreti di cooperazione e accoglienza fraterna da compiere da parte della Chiesa sia Siro-malabarese sia Latina: «Per la Chiesa Siro-malabarese, ciò consiste nella continuazione del prezioso lavoro dei loro sacerdoti e religiosi nei contesti latini e nella disponibilità verso quei fedeli siro-malabaresi che, pur scegliendo di frequentare le parrocchie latine, chiedono qualche assistenza alla loro Chiesa di origine. Da parte dei Latini, questa generosità può assumere la forma di accoglienza nei loro edifici delle comunità siro-malabaresi che non hanno ancora provveduto ai propri. Deve inoltre continuare la cooperazione tra tutte le Chiese sui iuris, come ritiri e seminari per il clero, i convegni sulla Bibbia, la celebrazione delle feste comuni, gli sforzi ecumenici. Con la crescita di amicizie spirituali e di reciproca assistenza, ogni tensione o apprensione dovrebbe essere rapidamente superata. Questa estensione degli spazi pastorali della Chiesa Siro-malabarese non sia in alcun modo percepita come una crescita di spazi di potere e di dominio, ma come una chiamata a vivere una comunione più profonda, che non può mai essere intesa come uniformità». ${ }^{70} \mathrm{Si}$ può soltanto sperare che tale invito di Papa Francesco venga accolto da tutti.

\footnotetext{
${ }^{69}$ Ibid.

${ }^{70}$ Ibid.
} 


\subsubsection{Uguaglianza nella Chiesa}

Una terza sfida che deve affrontare la Chiesa in India è la questione della uguaglianza dei fedeli nella Chiesa. Essa, infatti, vive nel suo interno la stessa difficoltà che la società indiana vive nei confronti dei dalit e delle donne.

Denunciando l'ingiusto sistema di divisione delle caste e le discriminazioni varie nella società indiana, Giovanni Paolo II aveva chiamato i fedeli dell'India a superare tali forme di negazione della dignità umana: «Ignoranza e pregiudizio devono essere sostituiti da tolleranza e comprensione. Indifferenza e lotta di classi devono tramutarsi in fratellanza e servizio impegnato. Le discriminazioni basate sulla razza, sul colore, sul credo, sul sesso o sull'origine etnica devono essere rifiutate come del tutto incompatibili con la dignità umana». ${ }^{71}$ Aveva messo in guardia specialmente i sacerdoti davanti alle problematiche di discriminazione in India: «Purtroppo, anche coloro che sono stati ordinati per il ministero, talvolta possono cadere vittima di tendenze culturali o sociali dannose, che minano la loro credibilità e ostacolano gravemente la loro missione. Come uomini di fede, i sacerdoti non devono consentire alla tentazione del potere o del guadagno materiale di distoglierli dalla loro vocazione, né possono permettere che le differenze etniche o di casta li distraggano dal loro compito fondamentale di diffondere il Vangelo». ${ }^{72}$

La Conferenza episcopale indiana $(C B C I)$ ha accolto questa sfida di affrontare la cultura di discriminazione nella società indiana e ha emanato dei documenti con varie indicazioni pratiche per superare tali problemi sia nella società indiana sia nella Chiesa.

\footnotetext{
${ }^{71}$ Giovanni Paolo II, Omelia Sollevate, porte durante la Messa celebrata nello stadio Indira Gandhi, New Delhi, 2 febbraio 1986, in https://w2.vatican.va/content/ john-paul-ii/it/homilies/1986/documents/hf_jp-ii_hom_19860202_indira-gandhi. html (consultato il 07 ottobre 2018).

${ }^{72}$ Giovanni Paolo II, Discorso Celebrate il Signore ai vescovi dell'India in visita ad limina apostolorum, 17 novembre 2003, in https://w2.vatican.va/content/john-paul-ii/it/speeches/2003/november/documents/hf_jp-ii_spe_20031117_ad-limina-india. html (consultato il 13 ottobre 2018).
} 


\section{a. Questione dalit}

Affrontando l'importante questione dei dalit, la CBCI ha promulgato "Policy of Dalit Empowerment in the Catholic Church in India. An Ethical Imperative to Build Inclusive Communities», nel $2016,{ }^{73}$ ben sapendo che 12 su 19 millioni dei cristiani in India sono dalit (n. 24). Dopo una lettura storica e biblica del fenomeno, i vescovi hanno offerto le strategie per il futuro, un piano d'azione per la $C B C I$ e delle raccomandazioni. Tra le strategie per il futuro (nn. 80-95), sono elencate le seguenti: proporre una risposta radicata nei valori evangelici e guidata dai principi della Costituzione indiana (nn. 82-84); assicurare i diritti uguali dei cristiani dalit e dei musulmani dalit (n. 85); rafforzare il potenziamento educativo ed economico (nn. 86-87); Sviluppare la leadership dei laici per l'azione politica (n. 88); rafforzare le strategie di attuazione e i meccanismi di monitoraggio (n. 89); promuovere i meccanismi di responsabilità e trasparenza (n. 90); costruire piattaforme di solidarietà per rafforzare il bene comune (nn. 91-92); creare rete (network) con persone di buona volontà e forgiare alleanze dei marginalizzati (nn. 93-95).

Viene proposto inoltre un piano d'azione per la $C B C I$ (n. 96): abolire ogni discriminazione, considerandola un peccato grave; creare una Commissione CBCI per Scheduled Castes \& Backward Castes con sacerdoti dalit; fare un censimento sui cristiani e sul loro stato socio-economico basato sulla loro casta, usare risorse online per $d a-$ lit; presentare alcune borse di studio; e seguire i processi giudiziari e gli appelli nella Corte Suprema sui dalit. Tra le raccomandazioni (nn. 97-98), vengono proposte le seguenti: elaborare piani d'azione a breve e lungo termine; abolire tutte le pratiche della discriminazione; promuovere e curare le vocazioni dei dalit al sacerdozio e alla vita religiosa; aumentare la trasparenza nella governance; dare spazio alle donne, ai bambini e ai giovani dalit; rafforzare i movimenti del

\footnotetext{
${ }^{73}$ Cf. Catholic Bishops' Conference of India, Policy of Dalit Empowerment in the Catholic Church in India. An Ethical Imperative to Build Inclusive Communities, 8 December 2016, in http://cbci.in/DownloadMat/dalit-policy.pdf (consultato il 21 novembre 2018).
} 
popolo; e incoraggiare l'educazione e l'imprenditorialità dei dalit. In questo modo si spera almeno di affrontare con coraggio il problema di discriminazione dei dalit nella società e nella Chiesa.

\section{b. Questione donne}

Sulla questione delle donne nella società e nella Chiesa, la Commissione per le donne della $C B C I$ ha preparato il seguente documento nel 2009: «Empowerment of Women in the Church and Society. Gender Policy of the Catholic Church of India». ${ }^{74}$ Nel documento, sono state individuate le seguenti "aree di attuazione: politiche e strategie" per la promozione dei diritti delle donne nella società civile e politica: donne e famiglia; donne ed educazione; donne e salute; e donne e partecipazione sociale, attraverso la promozione della partecipazione femminile alla vita pubblica e nelle strutture politiche statali, la loro indipendenza economica, il loro contributo per la pace e per la concordia religiosa e per l'ambiente.

Ha inoltre richiesto di prestare unattenzione speciale verso alcune problematiche prevalenti nella società indiana: diritti delle bambine; donne dalit e quelle tribali; violenza contro le donne (specie in media, nei posti di lavoro e nei luoghi pubblici); donne in circostanze difficili (violenza domestica specialmente verso le mogli, incesto, dote o dowry e lavoratrici domestiche); traffico e abuso sessuale delle donne. Per valorizzare il contributo delle donne nella Chiesa, ha suggerito la loro partecipazione negli organi amministrativi della $C B C I$, la loro presenza nel servizio sociale diocesano, la loro rappresentazione e partecipazione nelle strutture ecclesiali, e l'attenzione alla formazione delle donne consacrate e dei seminaristi.

Si spera che questi sforzi della Chiesa indiana aiutino a realizzare l'esortazione di Papa Francesco sulla presenza femminile: «E dunque un benefico processo quello della crescente presenza delle donne

\footnotetext{
${ }^{74}$ Cf. Commission for Women - Catholic Bishops' Conference of India, Empowerment of Women in the Church and Society. Gender Policy of the Catholic Church of India, 8 December 2009, in http://cbci.in/DownloadMat/Gender_Policy. pdf (consultato il 21 novembre 2018).
} 
nella vita sociale, economica e politica a livello locale, nazionale e internazionale, nonché in quella ecclesiale. Le donne hanno pieno diritto di inserirsi attivamente in tutti gli ambiti, e il loro diritto va affermato e protetto anche attraverso strumenti legali laddove si rivelino necessari». ${ }^{75}$

\subsubsection{Inculturazione e dialogo}

Un'altra sfida della Chiesa consiste senz'altro nella sua capacità di affrontare l'inculturazione e il dialogo sia interreligioso sia ecumenico.

\section{a. Inculturazione}

Quanto sono vere queste parole anche nel contesto indiano: «Immense regioni del mondo, soprattutto in Asia, continente di antiche culture, sono profondamente segnate da religioni e saggezze non cristiane, come l'Induismo, il Buddismo, il Taoismo, lo Shintoismo, il Confucianesimo, che meritano attenta considerazione. Il messaggio di Cristo vi suscita poche risposte. Forse perché qui il Cristianesimo è, troppo spesso, percepito come una religione straniera, non abbastanza inserita, assimilata e vissuta nelle culture locali?». ${ }^{76}$ Già Giovanni Paolo II invitava i cristiani in India all'inculturazione della fede: «Spetta ai cristiani d'oggi, innanzitutto a quelli dell'India, il compito di estrarre da questo ricco patrimonio gli elementi compatibili con la loro fede così che ne derivi un arricchimento del pensiero cristiano» (Fides et

\footnotetext{
${ }^{75}$ FranCESCO, Discorso Vi accolgo con gioia ai partecipanti alla plenaria del pontificio consiglio per il dialogo interreligioso, 9 giugno 2017, in https://w2.vatican. va/content/francesco/it/speeches/2017/june/documents/papa-francesco_20170609_ pontconsiglio-dialogo-interreligioso.html (consultato il 05 novembre 2018).

${ }^{76}$ Pontificio Consiglio della cultura, Per una Pastorale della cultura, 23 maggio 1999, n. 20, in http://www.vatican.va/roman_curia/pontifical_councils/cultr/ documents/rc_pc_pc-cultr_doc_03061999_pastoral_it.html (consultato il 08 ottobre 2018). Non si può che accettare questo giudizio della Recchi: «Non si può nascondere il fatto che la Chiesa è rimasta a lungo preoccupata dell'unità, interpretata soprattutto come uniformità di lingua, di stile, di gesti, di strutture e di disciplina. Ciò è durato secoli e durante tutto questo tempo essa non si è resa conto che aveva dato al Cristo soltanto un volto, quello europeo». Silvia Recchi, Diritto canonico e culture, in Quaderni di diritto ecclesiale 11 (1998) p. 436.
} 
Ratio 72) ${ }^{77}$ Non si dovrebbe dimenticare di cogliere i semi della fede già presenti nella società indiana: «Numerose realtà morali e spirituali, addirittura mistiche, quali la santità, la rinuncia, la castità, la virtù, l'amore universale, l'amore per la pace, la preghiera e la contemplazione, la felicità in Dio, la compassione, vissute in tali culture, costituiscono altrettante aperture verso la fede nel Dio di Gesù Cristo». ${ }^{78}$

Occorrerebbe anche "inculturare" ulteriormente il diritto, processo già in atto nel contesto indiano attraverso i vari modi di "adattamento del diritto canonico" (come si è visto precedentemente in questo contributo). Ciò deve avvenire continuamente nel contesto ecclesiale nazionale e regionale, accogliendo l'invito di Papa Francesco: «Inoltre, in ogni paese o regione si possono cercare soluzioni più inculturate, attente alle tradizioni e alle sfide locali. Infatti, le culture sono molto diverse tra loro e ogni principio generale ... ha bisogno di essere inculturato, se vuole essere osservato e applicato» (Amoris Laetitia 3). ${ }^{79}$ La Chiesa in India, dunque, deve avere il coraggio di confrontarsi con la propria radice, storia e cultura per proporre la fede cristiana $\mathrm{e}$ le conseguenti normative con il "linguaggio" indiano. ${ }^{80}$

\footnotetext{
${ }^{77}$ Giovanni Paolo II, Lettera Enciclica Fides et Ratio circa i rapporti tra fede e ragione, 14 settembre 1998, n. 72, in http://w2.vatican.va/content/john-paul-ii/it/ encyclicals/documents/hf_jp-ii_enc_14091998_fides-et-ratio.html (consultato il 12 ottobre 2018).

${ }^{78}$ Pontificio Consiglio della cultura, Per una Pastorale della cultura, 23 maggio 1999, n. 20.

${ }^{79}$ Francesco, Esortazione Apostolica Post-sinodale Amoris laetitiae sull'amore nella famiglia, 19 marzo 2016, n. 3, in http://w2.vatican.va/content/francesco/it/ apost_exhortations/documents/papa-francesco_esortazione-ap_20160319_amoris-laetitia.html (consultato il 09 ottobre 2018).

${ }^{80}$ «Il compito del diritto umano universale e quello particolare è perciò quello di garantire, di volta in volta, nel corso della storia, sia l'unità che la pluralità dell'unica Chiesa di Cristo realizzando nel modo umanamente migliore il principio ecclesiologico dell'in quibus e dell'ex quibus. Ciò esige da una parte che il diritto canonico universale umano-positivo deve poter essere applicabile nelle singole Chiese particolari senza forzature, evitando di confondere l'unità con l'uniformità; dall'altro che il diritto canonico particolare umano, per uno scorretto processo di inculturazione, non deve risultare eterogeneo al diritto delle altre Chiese particolari».
} 


\section{b. Dialogo inter-religioso ed ecumenico}

Giovanni Paolo II «esorta(va) i fedeli ad avviare, con prudenza e carità, il dialogo e la collaborazione con i membri delle altre religioni»: ${ }^{81}$ "La Chiesa cattolica in India ha promosso in modo costante la dignità di ogni persona umana e il corrispondente diritto di tutti i popoli alla libertà religiosa. Il suo incoraggiamento a tollerare e rispettare le altre religioni è dimostrato dai numerosi programmi di scambio interreligioso che avete sviluppato a livello sia nazionale sia locale. Vi incoraggio a proseguire questi dialoghi franchi e utili con gli appartenenti alle altre religioni. Tali discussioni ci aiuteranno a coltivare questa ricerca reciproca della verità, dell'armonia e della pace». ${ }^{82}$ E molto incoraggiante vedere tante manifestazioni di incontro e di dialogo inter-religioso che avvengono ogni giorno in India, non solo promosse dalla Chiesa cattolica.

Si dovrebbe incoraggiare anche il dialogo ecumenico (CIC can. $755 \$ 2$ ), soprattutto da parte delle Chiese cattoliche orientali sui iuris

E. Corecco, Ius universale - ius particolare, in Pontificium Consilium de Legum TeXtibus Interpretandis, Ius in vita et in missione Ecclesiae, Città del Vaticano 1994, pp. 565-566. Cf. Francis Eluvathingal, Inculturation and Church: A Canonical Overview, in Paul Pulikkan - Paul M. Collins (Eds.), The Church and Culture in India. Inculturation: Theory and Praxis, ISPCK, Delhi 2010, pp. 39-55. Cf. Geraldina Boni, Il Codex Iuris Canonici e le culture, in Stato, Chiese e pluralismo confessionale, Rivista telematica, settembre 2009, pp. 1-157.

${ }^{81}$ Benedetto XVI ha indicato delle regole d'oro per il dialogo interreligioso: «Per l'essenza del dialogo interreligioso, oggi in genere si considerano fondamentali due regole: 1 . Il dialogo non ha di mira la conversione, bensì la comprensione. In questo si distingue dall'evangelizzazione, dalla missione. 2. Conformemente a ciò, in questo dialogo ambedue le parti restano consapevolmente nella loro identità, che, nel dialogo, non mettono in questione né per sé né per gli altri». BENEDETTO XVI, Discorso Con grande gioia presentazione degli auguri natalizi della curia romana, 21 dicembre 2012, in https://w2.vatican.va/content/benedict-xvi/it/speeches/2012/ december/documents/hf_ben-xvi_spe_20121221_auguri-curia.html (consultato il 18 ottobre 2018).

${ }^{82}$ Giovanni Paolo II, Discorso Celebrate il Signore ai vescovi dell'India in visita ad limina apostolorum, 17 novembre 2003, in https://w2.vatican.va/content/john-paul-ii/it/speeches/2003/november/documents/hf_jp-ii_spe_20031117_ad-limina-india. html (consultato il 19 ottobre 2018). 
presenti in India (CCEO cann. 902-908): «Spetta alle Chiese orientali cattoliche il compito speciale di promuovere l'unità fra tutte le Chiese orientali anzitutto con la preghiera, con l'esempio della vita, con la religiosa fedeltà verso le antiche tradizioni delle Chiese orientali, con una migliore conoscenza vicendevole, con la collaborazione e la fraterna stima delle cose e dei cuori» (CCEO can. 903). Infatti, tale dialogo deve avvenire a livello teologico, «evitando i pericoli di un falso irenismo, dell'indifferentismo e dello zelo eccessivo» (CCEO can. 905). Si deve assicurare anche un dialogo spirituale (CCEO can. 907) e un dialogo sociale, cooperando con altri cristiani in varie iniziative, "come per esempio le opere di carità, di giustizia sociale, la difesa della dignità della persona umana e dei suoi diritti fondamentali, la promozione della pace, le date commemorative della patria, le feste nazionali» (CCEO can. 908).

Infatti, l'India è il luogo per eccellenza per il dialogo inter-religioso - essendo la culla delle religioni -, e per il dialogo ecumenico vivendo da secoli con varie Chiese nel suo seno.

\section{Conclusione}

La breve lettura storica delle realtà culturali indiane sia legislative sia ecclesiali e la presentazione delle sfide attuali - nella società civile e nella Chiesa - emergenti soprattutto dall'incontro tra la cultura canonica e la cultura giuridica indiana rivelano il volto luminoso della Chiesa cattolica in India, ove la fede cristiana è stata accolta, adottata, inculturata e celebrata, arricchendo a sua volta la cultura indiana.

Anche se le sfide da affrontare sia nella società sia nella Chiesa non sono semplici e facili, tuttavia la fede vissuta dai fedeli cristiani ci invita a guardare l'India con gioia e speranza, come illustrano chiaramente queste incoraggianti parole di Benedetto XVI ai vescovi dell'India: «Le più significative risorse concrete delle Chiese che guidate non sono gli edifici, le scuole, gli orfanotrofi, i conventi o le canoniche, ma gli uomini, le donne e i bambini della Chiesa in India che fanno vivere la fede, che rendono testimonianza della presenza amorevole di Dio attraverso vite di santità. Come parte di un patrimonio ricco e antico, l'India vanta una presenza cristiana antica 
e ragguardevole, che ha contribuito alla società indiana e ha recato beneficio alla vostra cultura in innumerevoli modi, arricchendo la vita di tantissimi cittadini, non solo cattolici. L'enorme benedizione della fede in Dio e nel suo Figlio, Gesù Cristo, di cui i membri della Chiesa recano testimonianza nel vostro Paese, li motiva ad agire in modo altruistico, gentile, amorevole e caritatevole (cf. 2Cor 5, 14). Ancor più importante è che la Chiesa in India proclama la sua fede e il suo amore alla società in generale, li realizza attraverso l'interesse per tutte le persone, in ogni aspetto della loro vita spirituale e materiale. Che essi siano ricchi o poveri, anziani o giovani, maschi o femmine, di antica tradizione cristiana o accolti nella fede di recente, la Chiesa non può non vedere nella fede dei suoi membri, individualmente e collettivamente, un grande segno di speranza per l'India e per il suo futuro». ${ }^{83}$

\section{Encounter Between Ecclesial Law and Indian Culture: Historical Overview and Contemporary Challenges}

"A culture that is steeped in wisdom, rich in human experience, and filled with spiritual values that point to God and his providence in human history", thus St. John Paul II - in his speech to the Bishops of India on 23 June 1979 - wished "to render respectful homage to the ancient culture of your land (India)".

Speaking of the encounter between the ecclesial law and Indian culture, in the first part, a brief historical overview of Indian cultural growth is presented specifically in two areas: the four stages of Indian legal culture (Ancient Hinduism, Muslim influence, Introduction of the English system and Modern complex legislative system), and some significant moments of the presence and growth of the Church in India. In the second part, one wishes to gather the contemporary challenges, which this "encounter" has given rise to, both in the civil society (on civil recognition and some legislative implications) and in the Church (on adaptation of canon law, relationship

\footnotetext{
${ }^{83}$ Benedetto XVI, Discorso Celebrate il Signore ai vescovi della Conferenza Episcopale dell'India in visita ad limina apostolorum, 19 settembre 2011, in https://w2.vatican.va/content/benedict-xvi/it/speeches/2011/september/documents/hf_ben-Xvi_spe_20110919_ bishops-india.html (consultato il 20 novembre 2018). Il corsivo è mio.
} 
between the sui iuris Churches, equality in the Church, inculturation and interreligious and ecumenical dialogue).

Parole chiavi: diritto ecclesiale; diritto canonico; storia ecclesiastica indiana; Conferenza Episcopale Indiana; diritto missionario; cultura indiana; sistema legislativo indiano; diritto personale; adattamento; uguaglianza; inculturazione; dialogo interreligioso; dialogo ecumenico

Keywords: Church law; canon law; Indian Church history; Catholic Bishops' Conference of India; missionary law; Indian culture; Indian legislative system; personal law, adaptation; equality; inculturation; inter-religious dialogue; ecumenical dialogue

\section{Nota SUlL'Autore}

Prof. Dr. Jesu Pudumai Doss è un salesiano (SDB) sacerdote da Chennai, India. Ha conseguito sei licenze in Letteratura inglese, Educazione, Diritto Civile, Diritti umani, Diritto Canonico e Diritto Canonico Orientale, oltre al Dottorato in Diritto Canonico (UPS, Roma, 2003). È Professore Ordinario, già Decano della Facoltà di diritto canonico della Università Pontificia Salesiana; Giudice esterno del tribunale di Prima Istanza per la regione Lazio presso il Vicariato di Roma; membro della commissione speciale per la trattazione delle cause di scioglimento del matrimonio in favorem fidei presso la Congregazione per la Dottrina della Fede; Difensore del Vincolo per la trattazione delle cause di dispensa del matrimonio rato et non consummato presso l'ufficio matrimoniale speciale alla Rota Romana; ed era Consultore della Congregazione per gli Istituti di Vita Consacrata e le Società di Vita Apostolica. Ha pubblicato molti libri e articoli in questi ambiti: educazione, diritto canonico e diritto civile (soprattutto diritto dei minori e dei giovani). 